\title{
Sanksi Hukum Terhadap Pelaku Tindak Kekerasan Terhadap Perempuan dan Anak
}

\author{
Taufiq \\ Fakultas Hukum Universitas Pekalongan, E-mail: andangharjanto@gmail.com
}

\begin{tabular}{l}
\hline Info Artikel \\
\hline \\
Keywords: \\
Legal; Sanctions; Violence \\
P-ISSN: 1412-6605 \\
E-ISSN: 2301-6426 \\
Taufik, \\
andangharjanto@gmail.com \\
Kata kunci: \\
Sanksi; Kekerasan; Anak.
\end{tabular}

\begin{abstract}
Violence against women and children is any act that results in physical and psychological suffering for women and children. Violence against women and children is a crime that can be subject to criminal sanctions. The government tries its best to eradicate and eliminate acts of violence against women and children, by enacting Law Number 23 of 2002 as amended by Law Number: 35 of 2014 concerning the first amendment to Law Number 23 of 2002 concerning child protection, which was amended again by Perpu Number: 1 of 2016 concerning the third amendment of Law Number: 23 of 2002 concerning child protection, and Law Number: 23 of 2004 concerning the Elimination of domestic violence. The provisions of the laws and regulations as mentioned above, although they contain heavy legal sanctions, in reality there are still many cases of violence against women and children. This study uses a normative juridical approach or library research. The conclusion from the research results is that heavy legal sanctions, without ethical awareness of law enforcement officials to commit to enforcing them, will not deter the perpetrators and others from committing acts of violence against women and children. Eradicating or eliminating violence against women and children requires comprehensive efforts from all components of the nation, starting with taking formal and non-formal preventive actions.
\end{abstract}

\begin{tabular}{l}
\hline Abstrak \\
\hline Kekerasan terhadap perempuan dan anak adalah segala perbuatan yang \\
berakibat penderitaan fisik maupun psikis terhadap perempuan dan anak. \\
Tindakan kekerasan terhadap perempuan dan anak merupakan kejahatan \\
yang dapat dikenakan sanksi pidana. Pemerintah berupaya maksimal untuk \\
memberantas dan menghapuskan tindakan kekerasan terhadap perempuan \\
dan anak, dengan mengundangkan Undang-undang Nomor : 23 Tahun \\
2002 sebagaimana telah diubah dengan Undang-undang Nomor : 35 Tahun \\
2014 tentang perubahan pertama Undang-Undang Nomor : 23 Tahun 2002 \\
tentang perlindungan anak, yang diubah lagi dengan Perpu Nomor : 1 \\
Tahun 2016 tentang perubahan ketiga Undang-undang Nomor : 23 Tahun \\
2002 tentang perlindungan anak, dan Undang-undang Nomor : 23 Tahun \\
2004 tentang Penghapusan kekerasan dalam rumah tangga. Ketentuan \\
peraturan perundang-undangan sebagaimana tersebut diatas, meskipun \\
memuat sanksi hukum yang berat, tetapi kenyataannya masih banyak terjadi \\
kasus kekerasan terhadap perempuan dan anak. Penelitian ini menggunakan \\
metode pendekatan yuridis normatif atau penelitian kepustakaan. Simpulan \\
hasil penelitian bahwa sanksi hukum yang berat, tanpa adanya kesadaran etis \\
aparatur penegak hukum untuk berkomitmen menegakkannya tidak akan \\
membuat jera para pelaku dan orang lain untuk tidak melakukan tindak \\
kekerasan terhadap perempuan dan anak. Pemberantasan atau penghapusan \\
kekerasan terhadap perempuan dan anak diperlukan upaya komprehensifdari \\
semua komponen bangsa, dimulai dengan melakukan tindakan preventif \\
formal maupun non formal.
\end{tabular}




\section{Pendahuluan}

Kekerasan berbasis gender dan anak, semakin meningkat, baik jumlah maupun bentuk dan modus operasinya yang semakin beragam.Faktor penyebab terjadinya kekerasan berbasis gender, sangat kompleks dan satu sama lain saling berkaitan. Factorfaktor tersebut, antara lain perangkat hukum yang belum mampu memberikan perlindungan kepada para korban, konsep bahwa perempuan adalah milik keluarga (asset), media yang kurang mendukung pemberitaan tentang kekerasan terhadap perempuan dan anak, pelayanan publik yag belum optimal, adat istiadat yang kadang melegalkan kekerasan, persoalan kemiskinan, interprestasi yang keliru pada ajaran agama, yang semua itu terbungkus dalam budaya patriarkhi. ${ }^{1}$

Komisi Nasional Anti Kekerasan terhadap Perempuan (Komnas Perempuan) mengeluarkan Catatan Tahunan (Catahu) tahun 2016, untuk memperingati Hari Perempuan Internasional setiap 8 Maret 2016. Komnas Perempuan memberikan catatan penting dan menyimpulkan bahwa pada tahun 2015 kekerasan terhadap perempuan memperlihatkan pola meluas, sehingga penting agar negara hadir secara maksimal untuk terlibat dalam pencegahan, penanganan, serta tindakan strategis untuk menjamin rasa aman perempuan korban. Temuan Komnas Perempuan mencatat bahwa kekerasan terhadap perempuan tidak hanya terjadi di ranah domestik atau rumah tangga maupun dalam relasi perkawinan, tetapi juga terjadi meluas di masyarakat umum maupun yang berdampak dari kebijakan negara. ${ }^{2}$

Tindak kekerasan terhadap perempuan dan anak pada dasarnya bukan suatu bentuk perbuatan kejahatan yang baru, selalu ada disetiap masa dalam suatu perkembangan peradaban manusia. Pada masa pra Islam kejahatan semacam ini sudah ada, seperti misal di masa jahiliyah para elite masyarakat apabila punya anak perempuan, maka akan dikubur hidup-hidup, karena malu punya anak perempuan, di era perbudakan dan era kolonialisme sering terjadi perkosaan, pencabulan dan eksploitasi terhadap perempuan dan anak. Yang menarik perhatian publik adalah kekerasan yang menimpa kaum perempuan dan anak, dimana pelaku dan korban berusaha untuk merahasiakan perbuatan tersebut dari pandangan public. ${ }^{3}$

Perkembangan dan kemajuan teknologi tidak sedikit memberi sumbangan terhadap maraknya tindak kekerasan terhadap perempuan dan anak yang saat ini menjadi persoalan yang mendunia, meskipun sebenarnya dari dahulu sudah menjadi persoalan yang mendunia, terbatasnya media cetak dan belum

${ }^{1}$ Aldila Arumita Sari\& Ani Purwanti, Penegakan Hukum Tindak Pidana Kekerasan Terhadap Perempuan Di Kota Demak, Masalah-Masalah Hukum, Jilid 47 No.3, Juli 2018, hlm 318

${ }^{2}$ Komisi Nasional Perempuan, 2016

${ }^{3}$ Soeroso, hadiati moerti, Kekerasan Dalam Rumah Tangga, (Jakarta : Sinar Grafika 2010), hlm 1 
ditemukannya media elektronik pada masa itu menjadikan sebab kurang tersebar luasnya tindak kekerasan terhadap perempuan dan anak itu. Perserikatan Bangsa Bangsa (PBB) menetapkan tindak kekerasan terhadap perempuan dan anak sebagai kejahatan kemanusiaan dan pelanggaran HAM (Hak Asasi Manusia) berat, yang wajib dikenakan sanksi hukum berat bagi pelakunya. Data tindak kekerasan terhadap perempuan dan anak sudah masuk dalam kategori darurat nasional yang perlu penanganan serius dari semua pihak yang berkepentingan, terutama pemerintah. Karena pemerintah berkkewajiban untuk menciptakan kondisi masyarakat yang aman, tenteram dan tertib. Sejak dahulu tindak kekerasan terhadap perempuan dan anak tidak hanya terjadi di Indonesia, tetapi terjadi di seluruh belahan dunia, seperti data yang dikeluarkan oleh UNIFEM PBB tentang kekerasan terhadap perempuan di Turki pada tahun 1988 yang dilakukan oleh pasangannya sebanyak 57,9 \%, di India pada tahun 1999 sebanyak 49 \%, di Amerika Serikat sebanyak 22,1 \%, di Bangladesh pada tahun 2000 sebanyak $60 \%{ }^{4}$

Kekerasan terhadap perempuan dan anak berupa perkosaan, pencabulan, sodomi, penganiayaan, pembunuhan, penterlantaran, pemaklsaan kehendak, dan segala perbuatan, sikap yang menjadikan sebab penderitaan fisik maupun psikis perempuan dan anak. Menurut pernyataan sikap Komnas Perempuan dalam siaran pers Mei 2016, sejak tahun 2013 melalui catatan tahunan (cataku) Komnas Nasional anti kekerasan terhadap perempuan sudah memberi peringatan keras tentang meningkatnya gang rape / perkosaan kolektif oleh sejumlah pelaku, antara lain mencuatnya kasus serius yang menimpa siswi dengan pelaku teman-teman sekolahnya, perempuan di perkosa kolektif di transportasi publik oleh lainnya. ${ }^{5}$ Data cataku 2016 dari Komnas Perempuan, menunjukkan kekerasan seksual yang terjadi di ranah personal dari jumlah kasus sebesar 321.752, maka kekerasan seksual menempati peringkat dua, yaitu dalam bentuk perkosaan sebanyak 72 \% (2.399 kasus), dalam bentuk pencabulan sebanyak 18 \% (601 kasus) dan pelecehan seksual sebanyak 5 \% (166 kasus). Ranah publik, dari data sebanyak 31 \% (2.399 kasus), jenis kekerasan terhadap perempuan tertinggi adalah kekerasan seksual (61 \%). Pelaku kekerasan seksual adalah lintas usia, termasuk anak-anak menjadi pelaku tindak kekerasan seksual. 6

Tindak kekerasan terhadap perempuan dan anak sulit untuk diberantas secara tuntas, akan tetapi tidak boleh pesimis harus terus berusaha semaksimal mungkin untuk menindak pelaku dari tindak kekerasa terhadap perempuan dan anak. Pemerintah Republik Indonesia telah berusaha memberantas tindak kekerasan terhadap perempuan dan anak dengan instrumen hukum

\footnotetext{
${ }^{4}$ Ayuresanf.wordpress.com/2014, 30 Nopember 2016 Jam 10.00

${ }^{5}$ www.youtube.com/Latansa 88 tanggal 30 Nopember 2016 jam 11.00

${ }^{6} \mathrm{ibid}$
} 
sebagaimana yang dituangkan di dalam perundang-undangan, akan tetatapi yang menjadi pertanyaan adalah Berdasarkan latar belakang permasalahan sebagaimana terurai diatas dirumuskan permasalahan, Sejauh manakah sanksi hukum dapat digunakan untuk memberantas tindak kekerasan terhadap perempuan dan anak.

\section{Metode Penelitian}

Jenis penelitian yang digunakan dalam menyusun penelitian ini adalah penelitian hukum normatif. Dengan menggunakan data sekunder. Penelitian hukum normatif mengutamakan penelitian kepustakaan, yaitu kegiatan mengumpulkan data dari berbagai literatur baik dari perpustakaan maupun tempat lain. ${ }^{7}$ Penelitian hukum normatif ini menitikberatkan pada asas-asas hukum, sistematika hukum, sinkronisasi hukum, sejarah hukum dalam pembentukan Mahkamah Konstitusi dan lembaga negara di Indonesia Penelitian ini menggunakan data sekunder. Alat pengumpulan data sekunder berupa buku-buku yang berkaitan dengan teori dan konsep objek penelitian, artikel terkait, literatur pada karya ilmiah dan lain sebagainya melalui studi literatur. ${ }^{8}$

\section{Hasil dan Pembahasan}

\section{Tindak Kekerasan Terhadap Perempuan dan Anak}

Kekerasan Didalam Kamus Besar Bahasa Indonesia, Diartikan Sebagai "Keras" atau "paksaan". 9 Apabila kata "kekerasan" dihubungkan dengan kata "perempuan dan anak" menjadi kekerasan terhadap perempuan dan anak, yang berarti tindakan pemaksaan terhadap perempuan dan atau anak untuk melakukan atau tidak melakukan suatu perbuatan yang tidak dikehendakioleh perempuan dan atau anak yang dipaksa oleh si pelaku. Kekerasan terhadap perempuan secara terminologi diartikan sebagai suatu tindakan yang berakibat timbulnya kesengsaraan atau penderitaan bagi perempuan baik fisik maupun nonfisik.

Di Indonesia kekerasan terhadap perempuan, dimasukkan ke dalam "kekerasan dalam rumah tangga" seperti yang tertuang dalam judul/sebutan UU No. 23 Tahun 2004 tentang "Penghapusan kekerasan dalam rumah tangga". Pembuat undang-undang beranggapan kekerasan terhadap perempuan itu banyak terjadi dalam rumah tangga, dan perempuan yang dimaksud lebih dominan "isteri". Pedapat yang demikian ini di dasarkan pada realita banyaknya angka perceraian yang inisiatif perceraiannya datang

7 Jarot Digdo Ismoyo, The Model of Management of the Masela Block Based on People's Welfare in Maluku, Jurnal Bestuur Vol. 8, Issue 2, December, 2020. hlm 87

${ }^{8}$ Ibid.

9 Qodratullah, M.Taqdir.2011.kamus besar bahasa Indonesia untuk pelajar.Jakarta.Badan Pengembangan dan Pembinaanbahasa Kementrian Pendidikan dan Kebudayaan Halaman 228 
dari pihak isteri dan mayoritas alasannya "tidak diberi nafkah atau alasan ekonomi" yang dapat diartikan "ditelantarkan", atau mungkin oleh sebab dominasi orang tua terhadap anak perempuan. Kenyataan yang sesungguhnya banyaknya juga kekerasan terhadap perempuan di luar rumah tangga.

Kekerasan dalam rumah tangga dalam pasal 1 ayat (1) UU No. 23 Tahun 2004 diartikan "setiap perbuatan terhadap seseorang terutama perempuan, yang berakibat timbulnya kesengsaraan atau penderitaan secara fisik, seksual, psikologis, dan/atau penelantaraan rumah tangga termasuk ancaman untuk melakukan perbuatan, pemaksaan, atau perampasan kemerdekaan secara melawan hukum dalam lingkup rumah tangga. Kekerasan realitanya tidak hanya terjadi terhadap perempuan dalam rumah tangga, tetapi juga terjadi terhadap anak-anak, oleh karena anak sebagai tunas, potensi dan generasi muda penerus cita-cita perjuangan bangsa memiliki peran strategis wajib dilindungi dari tindak kekerasan. Oleh karena itu pemerintah dalam rangka melindungi anak mengundangkan UU No. 23 Tahun 2002 sebagaimana yang telah diubah dengan UU No. 35 Tahun 2014 dan diubah lagi dengan Perpu No. 1 Tahun 2016 tentang perubahan kedua UU No. 23 Tahun 2002 tentang "perlindungan anak".

Kekerasan terhadap anak menurut ketentuan pasal 1 angka 16 UU No. 35 Tahun 2014 jo UU No. 23 Tahun 2002, diartikan setiap perbuatan terhadap anak yang berakibat timbulnya kesengsaraan atau penderitaan secara fisik, psikis, seksual, dan/atau penelantaran, termasuk ancaman untuk melakukan perbuatan pemaksaan atau perampasan kemerdekaan secara melawan hukum.Pengertian kekerasan sebagaimana terurai di atas, menegaskan bahwa kekerasan terhadap perempuan dan anak dapat berupa:
a. Kekerasan seksual
b. Kekerasan ekonomi
c. Kekerasan idiologi
d. Pembiaran

Kekerasan seksual dapat berupa pemerkosaan, pencabulan, pelecehan seksual, sodomi dan penganiyaan baik fisik maupun psikis untuk memuaskan gairah sex pelaku. Kekerasan ekonomi menjadi suatu yang mendominasi kekerasan dalam rumah tangga, menterlantarkan anak isteri bertahun-tahun dengan tidak memberikan uang nafkah yang berakibat menimbulkan penderitaan isteri dan anak yang berkepanjangan yang dapat mengancam masa depan anak. Kekerasan idiologi merupakan tindakan pemaksaan terhadap isteri dan atau anak untuk mengikuti idiologi yangtidak sejalan dengan idiologi isteri atau anak yang lazimnya disertai dengan ancaman dan atau penganiayaan badan. Adapun pembiaran merupakan tindakan 
kekerasan pasif, yaitu membiarkan anak dan isteri dalam keadaan teraniaya baik fisik maupun psikis dengan tanpa memberikan perlindungan dan atau pertolongan sedangkan dirinya mempunyai kemampuan dan kekuasaan untuk melindungi dan atau memberi pertolongan. Tindak kekerasan yang banyak terjadi di tengah masyarakat erat hubungannya dengan agresif manusia untuk mempertahankan diri agar survive. ${ }^{10}$ Kekerasan juga dapat terjadi sebagai akibat pola pikir matrialisme dan sikap egois. ${ }^{11}$ Saat ini kekerasan telah menjadi fenomena sosial yang kerap terjadi di masyarakat perkotaan maupun pedesaan.

Menurut teori agresif Frustasi (Frusttation-aggression theory) ada pertautan langsung antara derajad frustasi tertentu yang dialami seseorang dengan timbulnya kecendereungan bertingkah laku agresif. Perilaku agresif yang kerap berujung pada kekerasan dapat berakibat menimbulkan korban manusia dan atau hrta benda. Adapun menurut teori kekerasan pembelajaran sosial (social learning theory) perilaku kekerasan pada umumnya merupakan hasil proses pembelajaran dari interaksi individu dengan lingkungannya, dalam hal ini lingkungan sosialnya, termasuk lingkungan keluarga. ${ }^{12}$ Tindakan kekerasan apapun sebabnya saat ini sudah merambah dalam lingkup lingkungan kehidupan sosial masyarakat, baik dalam ruang public maupun ruang domestic (keluarga). Pelaku dari tindakan kekerasan itu mayoritas laki-laki, dan korbannya kebanyakan perempuan dan anak.

Kekerasan dalam ruang domestic (keluarga) yang disebabkan oleh adanya kekuasaan ditangan salah satu anggota keluarga, dalam hal ini umumnya laki-laki (suami) yang mempunyai kekuasaan terhadap isteri dan atau anak, dengan mudahnya memaksakan kehendaknya terhadap isteri dan atau anak, dan menurut M. Foucault kekerasan itu memang cenderung menindas. ${ }^{13}$ Tindak kekerasan secara teoritis tidak terjadi begitu saja, dalam arti pelaku tidak langsung melakukan tindakan kekerasan terhadap korbannya tanpa adanya faktor pemicu yang mendorong pelaku untuk melakukan kekerasan. Pemicu timbulnya kekerasan tidak banyak diungkap, kebanyakan para pakar maupun media hanya menyoroti korban dan akibat semata.

Teori pembelajaran (social learning theory) membedah penyebab terjadinya tindak kekerasan dari sudut interaksi individual patut dipertimbangkan sebagai instrument untuk menanggulani terus berkembangnya tindak kekerasan di masyarakat, tentunya interaksi individual semata tidak cukup

${ }^{10}$ Muhammad Jafar Anwar, Kekerasan dan Anti Kekerasan, Majalah Amanah No. 31 th. XVI, Edisi Oktober 2012, hal. 2.

${ }^{11}$ Glen D. Parge, Islam and non violance, dalam terjemah M. Taufiq Rahman. 1998, Yoyakarta. IKIS. Cet I, hal 78.

12 Ibid, hal 67.

${ }^{13}$ M. Foucault, Power/knowledge. Ponthen on Book, dalam makalah Yariyanto, pola penanganan korban kekerasan. 2011, hal 2. 
untuk mengetahui penyebab dari tindak kekerasan, interaksi individual hanya sebagai salah satu dari sekian banyak penyebab, akan tetapi pengaruh interaksi individual dalam lingkungan sosial memang cukup signifikan dalam pembentukan karakter individu. Undang-undang Nomor 1 Tahun 1974 tentang "perkawinan" telah memberikan kewajiban kepada suami untuk memberlakukan isteri dan anak dengan cara yang ma'ruf (baik) dengan tidak melakukan kekerasan terhadap isteri dan anak, dan ini merupakan bagian dari pembelajaran sosial dalam interaksi sosial dalam rumah tangga, sehingga akan tercipta lingkungan keluarga yang harmonis dan berkeadilan.

Pasal 33 UU No. 1 Tahun 1974 tentang "perkawinan", menagatakan :"suami isteri wajib saling cinta mencintai, hormat menghormati, setia dan memberi bantuan lahir batin yang satu kepada yang lain". Terealisirnya hak dan kewajiban suami isteri merupakan modal dasar terwujudnya keluarga bahagia dan kekal berdasarkan Ketuhanan Yang Maha Esa, yang dapat melahirkan anak-anak yang jauh dari perilaku kekerasan. Keluarga bahagia sejahtera merupakan embrio masyarakat adil dan makmur karena keluargalah orang pertama kali mendapatkan pendidikan keharmonisan sebuah keluarga sangat menentukn masa depan. ${ }^{14}$ Dilihat dari teori pembelajaran sosial, lingkungan keluarga sangat menentukan timbulnya tindakan kekerasan, karena itu menjadi sangat penting kualitas keluarga dalam penghapusan dan atau pencegahan kekerasan.

Pemerintah dalam usaha mencegah dan memberantas tindak kekerasan serta melindungi anak dari tindak kekerasan, selain dari mengundangkan UU No. 1 Tahun 1974 tentang "perkawinan", juga telah memberlakukan Kitab Undang-Undang Hukum Pidana (KUHP), Undang-undang Nomor 23 Tahun 2002 tentang "Perlindungan anak", Undang-undang Nomor 35 Tahun 2014 tentang "perubahan pertama Undang-undang Nomor 23 Tahun 2002 tentang "perlindungan anak", Perpu Nomor 1 Tahun 2016 tentang "perubahan kedua UU No. 23 Tahun 2002 tentang perlindungan anak", Undang-undang Nomor 23 Tahun 2004 tentang "penghapusan kekerasan dalam rumah tangga", dan lainnya. Realita fenomena tindakan kekerasan masih banyak terjadi ditengahtengah kehidupan masyarakat, baik itu tindak pemerkosaan, pencabulan, penganiayaan, pelecehan seksual maupun pembunuhan yang korbannya perempuan dan anak.

\section{Sanksi Hukum}

Tindak kekerasan terhadap perempuan dan anak, seperti perkosaan, pencabulan, pelecehan seksual, sodomi, penganiayaan dan pembunuhan

${ }^{14}$ Mukhsin, Menterlantarkan keluarga merupakan delik dimisionis, dalam Taufiq Hamami, 2013. Peradilan Agama Dalam Reformasi Kekuasaan Kehakiman di Indonesia. Jakarta, Tata Nusa, hal 210. 
sering terjadi di negara Indonesia, dan banyak kasus kekerasan telah diproses secara hukum dan mempidanakan para pelaku tindak pidana kekerasan. Sanksi hukum yangdiberikan oleh Undang-undang bagi pelaku tindak kekerasan seperti yangtertuang dalam Perpu No. 1 Tahun 2016 tentang "Perubahan kedua UU No. 23 Tahun 2002 tentang Perlindungan Anak" cukup bervariatif dan sampai sanksi yang berat. Sanksi pidana bagi pelaku tindak pidana kekerasan tertuang di dalam pasal 81 dan pasal 81 A, 82, 82A perpu Nomor :1 Tahun 2016. Di dalam pasal 81 Perpu Nomor 1 Tahun 2016, dinyatakan:

a. Setiap orang yang melanggar ketentuan sebagaimana dimaksud dalam Pasal 76D dipidana dengan pidana penjara paling singkat 5 (lima) tahun dan paling lama 15 (lima belas) tahun dan denda paling banyak Rp5.000.000.000,00 (lima miliar rupiah).

b. Ketentuan pidana sebagaimana dimaksud pada ayat (1) berlaku pula bagi setiap Orang yang dengan sengaja melakukan tipu muslihat, serangkaian kebohongan, atau membujuk Anak melakukan persetubuhan dengannya atau dengan orang lain.

c. Dalam hal tindak pidana sebagaimana dimaksud pada ayat (1) dilakukan oleh orang tua, wali, orang-orang yang mempunyai hubungan keluarga, pengasuh anak, pendidik, tenaga kependidikan, aparat yang menangani perlindungan anak, atau dilakukan oleh lebih dari satu orang secara bersama-sama, pidananya ditambah $1 / 3$ (sepertiga) dari ancaman pidana sebagaimana dimaksud pada ayat (1).

d. Selain terhadap pelaku sebagaimana dimaksud pada ayat (3), penambahan 1/3 (sepertiga) dari ancaman pidana juga dikenakan kepada pelaku yang pernah dipidana karena melakukan tindak pidana sebagaimana dimaksud dalam Pasal 76D.

e. Dalam hal tindak pidana sebagaimana dimaksud dalam Pasal 76D menimbulkan korban lebih dari 1 (satu) orang, mengakibatkan luka berat, gangguan jiwa, penyakit menular, terganggu atau hilangnya fungsi reproduksi, dan/atau korban meninggal dunia, pelaku dipidana mati, seumur hidup, atau pidana penjara paling singkat 10 (sepuluh) tahun dan paling lama 20 (dua puluh) tahun.

f. Selain dikenai pidana sebagaimana dimaksud pada ayat (1), ayat (3), ayat (4), dan ayat (5), pelaku dapat dikenai pidana tambahan berupa pengumuman identitas pelaku.

g. Terhadap pelaku sebagaimana dimaksud pada ayat (4) dan ayat (5) dapat dikenai tindakan berupa kebiri kimia dan pemasangan alat pendeteksi elektronik. 
h. Tindakan sebagaimana dimaksud pada ayat (7) diputuskan bersamasama dengan pidana pokok dengan memuat jangka waktu pelaksanaan tindakan.

i. Pidana tambahan dan tindakan dikecualikan bagi pelaku Anak."

Ancaman sanksi hukum yang tersebut dalam ketentuan perundangundangan sebagaimana terurai diatas cukup berat. Akan tetapi apakah ancaman sanksi hukum tadi efektif untuk membuat jera para pelaku tindak kekerasan atau calon-calon pelaku jera atau tidak ?, Realita yang terjadi masih banyak pelaku-pelaku dan atau orang lain yang melakukan tindak kekerasan terhadap perempuan dan anak. Ancaman hukuman yang berat tidak akan ada manfaatnya untuk memberi perlindungan hukum para korban pelaku tindak kekerasan, kalau tidak ada kesungguhan atau kesadaran etis dari aparatur penegak hukum untuk menindak para pelaku tindak kekerasan. Kesadaran etis para aparatur penegak hukum sangat diperlukan untuk menegakkan hukum dan keadilan, sehingga hukum mampu dan berdaya guna untuk memberikan perlindungan terhadap para korban tindak pidana kekerasan terhadap perempuan dan anak.

Di dalam kasus pencabulan terhadap 2 (dua) anak perempuan yang terjadi di Pekalongan pada tahun 2015, seperti yang tertuang dalam putusan Pengadilan Negeri Pekalongan Nomor : 35/Pid.sus/2015/PN.Pkl dan Nomor :36/Pid.sus/2015/PN.Pkl tertanggal 8 Juli 2015, di dalam putusan sela 2 (dua) perkara pidana tersebut surat dakwaan jaksa penuntut umum dinyatakan batal demi hukum, karena tidak memenuhi syarat materiil dakwaan, sehingga terdakwa bebas. Putusan Pengadilan Negeri Pekalongan tersebut sebagai fakta hukum, jaksa penuntut umum tidak profesional, tidak memiliki kesadaran etis sebagai aparatur penegak hukum, yang berakibat pelaku tindak pidana pencabulan bebas tidak terjerat sanksi hukum, dan ini sangat merugikan korban pencabulan dan menjadikan disfungsionalisnya UU Nomor : 35 Tahun 2014 tentang perubahan pertama UU No. 23 Tahun 2002 tentang perlindungan anak. Jaksa penuntut umum di dalam surat dakwaannya menjerat terdakwa dengan pasal 81 ayat (1) jo pasal $76 \mathrm{D}$ Undang-Undang RI Nomor: 35 Tahun 2014 tentang "perubahan pertama UU No. 23 Tahun 2002 tentang perlindungan anak".

Pasal yang dijeratkan pada terdakwa dalam surat dakwaan jaksa penuntut umum di dalam putusan Pengadilan Negeri Pekalongan No. 35/Pid.sus/2015/PN.Pkl dan UU No. 36/Pid.sus/2015/PN.Pkl cukup berat, yaitu melanggar pasal 81 ayat (1) jo pasal 76D UU No. 35 Tahun 2014. Ancaman sanksi pidana yang tertuang dalam pasal 81 ayat (1) UU No. 35 Tahun 2014 paling singkat 5 (lima) tahun dan palinglama 15 (lima belas) tahun penjara dan denda paling banyak Rp. 5.000.000.000 (lima milyar rupiah). 
Adapun bunyi rumusan pasal 76D UU No. 35 Tahun 2014 sebagai berikut : "setiap orang dilarang melakukan kekerasan memaksa anak melakukan persetubuhan dengannya atau dengan orang lain". Ancaman sanksi pidana yang berat, tidakakan ada artinya buat korban dan buat siapapun apabila aparat penegak hukum tidak memiliki kesadaran etis dan tidak profesional seperti jaksa penuntut umum dalam putusan Pengadilan Negeri Pekalongan tersebut diatas. Dua putusan tersebut sekedar contoh fakta hukum ancaman sanksi hukum yang tidak berfungsi sama sekali untuk memberantas tindak kekerasan terhadap perempuan dan anak.

Kasus semacam itu terkadang ditingkat penyidikan kepolisian selesai dengan rekayasa perdamaian antara pelaku dengan korban, dimana korban menerima sejumlah uang dari pelaku dan atau darai keluarga pelaku. Kelemahan mentalitas aparatur penegak hukum, kelemahan mentalitas atau ketidaksiapan pelaku untuk diterapkan suatu hukum dan kelemahan ekonomi korban pencabulan, perkosaan atau kekerasan lainnya yang berhubungan dengan kekerasan seksual itu kadang menjadi salah satu sebab tidak dapat berfungsinya hukum dan atau sanksi hukum untuk menjerat para pelaku tindak kekerasan terhadap perempuan dan anak, karena itu tindak kekerasan terhadap perempuan dan anak sulit untuk diberantas tuntas, dan kenyataannya kasus kekerasan terus terjadi di tengah masyarakat, meskipun pemerintah berulangkali melakukan perubahan undang-undang dengan memperberat sanksi pidana bagi para pelanggarnya.

Kejahatan apapun memang tidak dapat diberantas secara tuntas dengan hanya menerapkan sanksi hukum, lebih-lebih apabila tidak ada kesadaran etis dari aparatur penegak hukum untuk bersungguh memberantasnya, karenanya agar sanksi hukum berlaku efektif sebagaiinstrumen untuk memberantas dan mencegah tindak kekerasan terhadap perempuan dan anak dibutuhkan mentalitas aparatur penegak hukum dan mentalitas masyarakat yang kuat berkehendak tegaknya hukum dan keadilan. Sanksi hukum yang berat semata tidak cukup untuk memberantas dan mencegah tindak kekerasan terhadap perempuan dan anak, karena itu diperlukan upaya hukum yang komprehensif. Perlu dilakukan tindakan preventif di masyarakat, dengan memberikan sosialisasi perundang-undangan terkait dengan tindakan kekerasan terhadap perempuan dan anak, melalui pendidikan formal dan non formal. Peran orangtua, tokoh masyarakat sangat dibutuhkan dalam upaya preventif timbulnya tindak kekerasan terhadap perempuan dan anak. Upaya preventif ini harus dimulai dari keluarga/rumah tangga. Pembelajaran sosial yang berkualitas di dalam rumah tangga atas dasar iman dan taqwa menjadi sangat penting untuk tumbuh kembangnya generasi yang berkualitas iman dan taqwa, sehingga 
tindak kekerasan terhadap perempuan dan anak tidak akan terjadi lagi di masyarakat.

\section{Kesimpulan}

Dari uraian di atas dapat disimpulkan sebagai berikut : Pertama, Sanksi hukum yang berat, tanpa adanya kesadaran etis aparatur penegak hukum untuk berkomitmen menegakkannya tidak akan membuat jera para pelaku dan orang lain untuk tidak melakukan tindak kekerasan terhadap perempuan dan anak, Kedua, Pemberantasan atau penghapusan kekerasan terhadap perempuan dan anak diperlukan upaya komprehensif dari semua komponen bangsa, dimulai dengan melakukan tindakan preventif formal maupun non formal

\section{REFRENCES}

Glen D. Parge, Islam and non violance, dalam terjemah M. Taufiq Rahman. 1998, Yoyakarta. IKIS. Cet I.

Akhmaddhian, Suwari. Discourse on Creating a Special Environmental Court in Indonesia to Resolve Environmental Disputes, Jurnal Bestuur Vol. 8, Issue 2, December, 2020.

Saputra, Rian, Development of Creative Industries as Regional Leaders in National Tourism Efforts Based on Geographical Indications, Jurnal Bestuur Vol. 8, Issue 2, December, 2020.

M. Foucault, Power/ knowledge. Ponthen on Book, dalam makalah Yariyanto, pola penanganan korban kekerasan. 2011.

Gunawan, Said, The Principle of Control of Non Primary Gun System of the Indonesian National Army Protect Soldiers, Jurnal Bestuur Vol. 8, Issue 2, December, 2020.

Muhammad Jafar Anwar, Kekerasan dan Anti Kekerasan, Majalah Amanah No. 31 th. XVI, Edisi Oktober 2012.

Hanum, W.N, Setting of Earth Oil Management in Old Wells Based on the Principle Social Justice, Jurnal Bestuur Vol. 8, Issue 2, December, 2020.

Mukhsin, Menterlantarkan keluarga merupakan delik dimisionis, dalam Taufiq Hamami, 2013. Peradilan Agama Dalam Reformasi Kekuasaan Kehakiman di Indonesia. Jakarta, Tata Nusa.

Abdul Kadir Jaelani, "Implementasi Daluarsa Gugatan Dalam Putusan Peradilan Tata Usaha Negara Di Indonesia", Jurnal Pena Justisia, Vol.18, Nomor 2 Tahun 2019.

Nurika Latiff Hikmawati "Efektivitas Penerapan Sanksi Pidana Penjara Terhadap Anak Yang Melakukan Tindak Pidana", Jurnal Pena Justisia, Vol.18, Nomor 2 Tahun 2019.

Miftahur Rahman Hakim, Nur Kholidah, "Hak Merek Sebagai Jaminan Gadai Untuk Permodalan Umkm Industri Kreatif Kerajinan Batik", Jurnal Pena Justisia, Vol.18, Nomor 2 Tahun 2019.

Vidya Noor Rachmadini "Perlindungan Hukum Bagi Investor Dalam Pasar Modal Menurut Undang-Undang Pasar Modal Dan Undang-Undang Otoritas Jasa Keuangan", Jurnal Pena Justisia, Vol.18, Nomor 2 Tahun 2019. 
Willy Naresta Hanum, "Setting of Earth Oil Management in Old Wells Based on the Principle Social Justice", Jurnal Bestuur, Volume 8, Nomor 2 Tahun 2020.

Resti Dian Luthviati, "The Role of Local Governments in the Defense of Leading Products", Jurnal Bestuur, Volume 8, Nomor 2 Tahun 2020.

Pane, E \& Yanis, A.M, Reconstruction of Mining Policies on Justice in Lampung Province, Jurnal Bestuur Vol. 8, Issue 2, December, 2020.

Qodratullah, M.Taqdir.2011.kamus besar bahasa Indonesia untuk pelajar.Jakarta.Badan Pengembangan dan Pembinaanbahasa Kementrian Pendidikan dan Kebudayaan.

Jaelani, A.K, Implementasi Daluarsa Gugatan Dalam Putusan Peradilan Tata Usaha Negara di Indonesia, Pena Justisia: Media Komunikasi dan Kajian Hukum. Volume 18, No. 2, 2019.

Intaniasari, Kirana, Gross Split Contract Framework Regulation on the Caring for People, Jurnal Bestuur Vol. 8, Issue 2, December, 2020.

Luthviati, R.D, The Role of Local Governments in the Defense of Leading Products, Jurnal Bestuur Vol. 8, Issue 2, December, 2020. 